\title{
Indigenous Srimpi Pandelori As Android-Based Civic E-Learning Media Toward Students' Creative Thinking Skills Engagement
}

\author{
Serlina Candra Wardina Sari ${ }^{1}$, Mukhamad Murdiono², Kharisma Fenditasari ${ }^{3}$, \\ Isna Sari Rukmana ${ }^{4}$ \\ ${ }^{1,4}$ Civic Education, Postgraduate Program, Universitas Negeri Yogyakarta, Indonesia \\ ${ }^{2}$ Doctor, Department of Civic Education, Universitas Negeri Yogyakarta, Indonesia \\ ${ }^{3}$ Physics, Postgraduate Program, Universitas Negeri Yogyakarta, Indonesia \\ e-mail: serlinacandra.2018@student.uny.ac.id, mukhamad_murdiono@uny.ac.id, \\ kharismafenditasari.2018@student.iuny.ac.id, isnasari.2018@student.uny.ac.id
}

\begin{abstract}
Learning media development has been a current issue in civic education. Involving to analyze indigenous Srimpi Pandelori dance based-android civic e-learning media effect aims to facilitate the 4.0 era demand. Indeed, practicing $21^{\text {st }}$-century skills focused on creative thinking skills. Research methodology uses a quantitative approach, and a quasi-experimental study is used regarding onegroup pretest-posttest design. Creative thinking skills test conduct for pretest and posttest question consisting of ten multiple-choice questions according to high order thinking skills criteria then checked for the Content Validity Index. To conclude, indigenous Srimpi Pandelori dance based-android media civic e-learning significantly influences students' creative thinking skills on Pancasila values. Besides, it can improve students' creative thinking skills on Pancasila values of 0.48 in the medium category.
\end{abstract}

Keywords: Srimpi Pandelori Dance; Civic E-Learning; Creative Thinking Skills.

\section{Introduction}

In $21^{\text {st }}$-century learning process encourages students' great attitudes and instructional behaviors and has an impact on various fields, especially education (Jacobson, Seavey, \& Mueller, 2016, p. 33). Self-preparation becomes a competitive human resource that is necessary in order to be able to compete in the real competition (Triyono, Senam, Jumadi, \& Insih, 2017, p. 215). This study aims to conductive and utilizes thinking skills. They are critical thinking skills, problem-solving, creative thinking skills, collaboration, leadership, adaptability, effective communication both orally and in writing, spirited entrepreneur, accessing and analyzing information (Gu, Ap, \& Simone, 2019, p. 97; Ritter \& Mostert, 2017, p. 248; Safitri, Sunu, \& Endang, 2018, p. 232). Thinking skills can integrate newly acquired knowledge, and it assimilates knowledge according to their expertise (Hendikawati, Zahid, \& Arifudin, 2019, p. 392). Creative thinking skills can conduct higher-order thinking skills (HOTs) embodiment and engaged students to develop original, aesthetic, and constructive ideas (Martiniano, 2017, p. 172; Tur \& Marín, 2014, p. 48). To add, it can relate rational views and concepts in unusual solving, high-quality, and task-appropriate problems. Therefore, creative thinking skills for students' 21 st engagement skills necessary.

Students' creative thinking skills is a complex education learning part due to it has several indicators: fluency, flexibility, originality, and elaboration. However, learning is still not entirely practicing creative thinking skills (Harris \& Leon R, 2018, p. 241). Whereas students must have creative thinking skills in studying civic education due to developing a good ability and aesthetically original (Ige \& Hlalele, 2017, p. 15). Tasks, stimuli, and questions in civic education learning have not been designed to accommodate students' creative thinking skills (Stoddard, Banks, Christine, \& Elizabeth, 2016, p. 11). Besides, high school level creative thinking skills task is limited. Whereas it can build creative thinking skills in the learning process due to conduct an interactive learning process (Diani, Yuberti, \& Syarlisjiswan, 2018, p. 111). Indeed, the tedious and boring learning process decreases, and students' civic creative thinking skill development can conduct. Thus, learning media development, creating students' creative thinking skills in civic education, needs to concoct due to facilitate the 4.0 era demands for learners' creative thinking skills integration (Bortolini, Ferrari, Gamberi, Pilati, 
\& Faccio, 2017, p. 5703). Moreover, it will enhance students' access to technology and digital resources instruction.

E-learning system refers to the technology used, information, and internet-based communication to improve knowledge and skills during instruction (Ahangari \& Samadian, 2014, p. 124); Mayer, 2017, p. 414). Moreover, it conducted a positive influence on educational transformation in conventional forms to digital form both content and system used (Tur \& Marín, 2014, p. 51). While conventional education is limited on the face to face meeting number and the delivering concept making instruction hampered (Redecker \& Johannessen, 2013 , p. 82). Therefore, creative and innovative learning media development needs to conduct in order to progress and engages both in terms of students' knowledge and skills.

Civic education learning requires students to develop all aspects of knowledge, attitudes, and skills (Ige \& Hlalele, 2017, p. 13). Civic education carries missions and talk about values, morals, and norms as an effort to foster, uphold, and develop moral order in community activities (Prihandoko, Slamet, \& Winarno, 2017, p. 201). Indeed, the first grade of senior high students has to learn Pancasila values as a basic guideline in dealing with daily life (Suratno, Nurul, Yushardi, Daflik, \& Iwan, 2019, p. 141). Engaging conceptual basic toward the civic education learning process is prominent relating to Indonesian fundamental values. Every human being has the potential to be following the nature of human creation at birth, but in his life requires a long process, one of which is developed through the world of education (Sukoyo, 2017 , p. 164). Students have to learn the ground theory and concepts on studying Pancasila values as the basis for knowledge of the principles of life (Sitorus, 2016, p. 703). Learning must provide meaningful learning to present the knowledge students need to solve a problem in learning to get optimal learning results (Widiana, I Made, \& Ni Putu, 2019, p. 17). Therefore, learning media development integrated android platform-based technology will effectively support the civic learning process in the 4.0 era. This e-learning media is creatively, innovatively, and educatively. Moreover, it is not matched with an evaluation following creative thinking skill indicators. Therefore, android based-civic e-learning development is prominent to conduct due to students' creative thinking skills engagement on Pancasila values.

Srimpi Pandelori dance is a classical dance in Yogyakarta (Taib, Gabriel, Soedarsono, \& A.M. Hermien, 2014, p. 50). It has a good theme and consists of human life values that are relevant to the Pancasila value points (Tyas, 2018, p. 184). Countries that have a variety of ethnicities, languages, religions, cultures, and other social groups have their challenges. The challenge of the Indonesian people is to maintain Bhinneka Tunggal lka into a democratic society based on Pancasila values (Japar, Dini, Yuyus, Yasnita, \& Sarkadi, 2018, p. 334). Personality values is one of important value (Tyas, 2018, p. 186) due to Indonesian ideology value, Pancasila. Hence, Srimpi Pandelori dance needs to introduce in instruction Pancasila.

Srimpi Pandelori dance is a local Indonesian culture and is one of the indigenous knowledge in Indonesia (Meinal \& Rahmawati, 2016, p. 429). Local culture is an important property for emotionally binding power. However, the young Indonesian generation ignores the local culture (Martiniano, 2017, p. 177). Even though it can help both preserving the nation's culture is lock-on and conducting patriotism. The more integrating indigenous Srimpi Pandelori focused on, the more valuable instruction conducted to local culture is transmitted from generation to generation.

Difficulty in time means and infrastructures. Introducing the local culture to the young generation becomes an obstacle that needs an innovation to cope with the problems $(\mathrm{Im}$, Brad, \& Kim, 2015, p. 137; Komara, 2017, p. 28). Learning media become a solution to instruction difficulties break up (Safara, M. Zaim, \& Refnaldi, 2019, p. 1021). Besides, almost all high school students use android as a means of communication. Android use in learning may become a learning innovation. Learners are more interested in using android e-learning media due to use anywhere (Widiansyah, Indriwati, Munzil, \& Fauzi, 2018, p. 47). Android also assists the students to interact, and tasking build-up (Gitadewi, 2019, p. 71). Civic android learning media is important to develop while the indigenous knowledge Srimpi Pandelori dance to show to young Indonesian generation. Therefore, civic android learning media integrating Srimpi Pandelori dance can be the best solution to increase students' creative thinking skills toward Pancasila values. The learning media development research indigenous 
Srimpi Pandelori android platform-based civic e-learning media toward students' creative thinking skills engagement will describe students' creative thinking skills ability.

\section{Method}

The research methodology is a quasi-experimental study with one group pretest-posttest design. The learning process uses indigenous Srimpi Pandelori dance based-android civic elearning media is used to train the high school students' creative thinking skills and introduce Indonesian cultures focused on Yogyakarta exceptional dance.

This research was conducted in Sleman Regency, Yogyakarta, Indonesia. Used 36 students as subjects. They are first grade at SMA Negeri 1 Ngaglik, Sleman, Yogyakarta. The test used in this study aims to collect data consisting of pretest and posttest creative thinking skills questions. In the test, there are ten multiple-choice questions with HOTs criteria for creative thinking. Two expert judgments deeply analyze validation.

Creative thinking skills were analyzed using $\mathrm{N}$-gain. However, in the previous stage, normality tests were done as a prerequisite. Besides, hypothesis testing is also carried out to determine significance. Further explained with normality test, hypothesis, and n-gain. The normality test is used to see the distribution of student values in one class, whether pretest and posttest results are normally distributed or not. SPSS application is used to conduct a normality test.

This hypothesis test is used to test the hypothesis that has been submitted. Hypothesis testing is done by t-test to find out the different power of students' creative thinking skills on Pancasila values between before and after using indigenous Srimpi Pandelori dance basedandroid civic e-learning media toward students' creative thinking skills (Hartono, 2016: 146). Decision making for hypothesis using acceptance or rejection criteria of the naught hypothesis $\left(H_{0}\right)$ at the level significance $5 \%$ is if $\quad t$ count $>t t_{a b l} \mathrm{e}$ accordingly naught hypothesis $\left(H_{0}\right)$ rejected or alternative hypothesis $\left(H_{a}\right)$ accepted. However, in case $t \quad$ count $<t$ tabl $\mathrm{e}$, then the null hypothesis $\left(H_{0}\right)$ accepted or alternative hypothesis $\left(H_{a}\right)$ rejected.

$\mathrm{N}$-gain value to find out the increase in students' creative thinking skills between before and after being treated, the $\mathrm{n}$-gain formula is used, namely:

$$
<\mathrm{g}>\frac{(\text { Spost }- \text { Spre })}{(100-\text { Spre })}
$$

Subsequently, interpretation is presented in Table 1.

Table 1. Classification of $n$-gain interpretations

\begin{tabular}{cc}
\hline Substantial Percentage & Interpretation \\
$\mathrm{g} \geq 0,7$ & High \\
$0,3 \leq \mathrm{g}<0,7$ & Medium \\
$\mathrm{g}<0,3$ & Low \\
\hline
\end{tabular}

\section{Findings and Discussion}

in Table 2.

Research data score creative thinking skills based on the pretest-posttest represented

Table 2. Creative thinking skills data

\begin{tabular}{ccc}
\hline Data Source & \multicolumn{3}{c}{ Class } \\
\cline { 2 - 3 } & Pretest & Posttest \\
\hline Min & 0 & 50 \\
Max & 80 & 90 \\
Mean & 50 & 75 \\
Median & 45 & 80 \\
\hline
\end{tabular}


Table 2, the creative thinking skills average score is quite far adrift. The pretest score mean was 50 , while the posttest score means was 75 . The test results after treatment with Android Srimpi Pandelori dance based-civic e-learning had a higher average score before. The normality test is performed on pretest and posttest data. Table 3 indicates that pretest and posttest values have a significant value above 0.05 so that the data can be generated normally distributed.

Table 3. Pretest and posttest normality test of students' creative thinking skills

\begin{tabular}{llll}
\hline & & Shapiro-Wilk & \\
\hline Class & Statistic & Df & Sig. \\
Pretest & 0,924 & 36 & 0,017 \\
Posttest & 0,905 & 36 & 0,006 \\
\hline
\end{tabular}

The hypothesis proposed that $\mathrm{HO}$, there is no effect of indigenous Srimpi Pandelori android platform-based civic e-learning media toward students' creative thinking skills engagement at SMA Negeri 1 Ngaglik on Pancasila values. Then, Ha, there is an effect of indigenous Srimpi Pandelori android platform-based civic e-learning media toward students' creative thinking skills engagement at SMA Negeri 1 Ngaglik on Pancasila values.

Calculation results of the t-test are carried out using the assumption that both variances are assumed to be equal (equal variances assumed) represented in Table 4.

Table 4. T-test results of students creative thinking skills on n-gain data

\begin{tabular}{|c|c|c|c|c|c|}
\hline \multirow[t]{2}{*}{$\begin{array}{c}\text { Students' } \\
\text { creative } \\
\text { thinking skills }\end{array}$} & \multicolumn{2}{|c|}{$\begin{array}{l}\text { Levene's test for } \\
\text { equality of } \\
\text { variances }\end{array}$} & \multicolumn{3}{|c|}{ t-test for Equality of Means } \\
\hline & $\mathbf{F}$ & Sig. & $T$ & df & Sig. (2-tailed) \\
\hline $\begin{array}{l}\text { Equal variances } \\
\text { assumed }\end{array}$ & 23,142 & 0,000 & $-6,323$ & 70 & 0,000 \\
\hline $\begin{array}{l}\text { Equal variances } \\
\text { not assumed }\end{array}$ & & & $-6,323$ & 52,209 & 0,000 \\
\hline
\end{tabular}

Table 4 indicate that $t$-value grade for the same gain variance is $-6,323$ with a degree of freedom 70 and a significance value of 0,000 . While, the t-value for $\mathrm{df}=70$ is 1,994 . The significance level of the calculated value $<0.05$ concluded that $\mathrm{HO}$ is rejected $\mathrm{Ha}$ is accepted. Therefore, there is a significant effect of indigenous Srimpi Pandelori android platform-based civic e-learning media toward students' creative thinking skills engagement at SMA Negeri 1 Ngaglik on Pancasila values. Enhancing students' creative thinking skills was calculated as a whole class average using n-gain calculations. Pretest and posttest results on 36 students experienced enhancing creative thinking skills on Pancasila values, which can be seen in Table 5.

Table 5. N-gain data

\begin{tabular}{ccc}
\hline Number of samples & $\mathrm{N}$-gain average & Classification \\
\hline 36 & 0,48 & Medium \\
\hline
\end{tabular}

Table 5 showed that the $n$-gain value was 0,48 in the medium category. It means that android indigenous Srimpi Pandelori dance-based creative thinking media significantly gain learners' creative skills cognitive bracket for aged 15-16, influencing both high-to medium leaners and low-to-medium. The Effect of Indigenous Srimpi Pandelori Android PlatformBased Civic E-Learning Media Toward Students' Creative Thinking Skills. This product is civic education learning media on Pancasila values within the framework practice of implementing state government. This media is applied on the android platform based mobile phones to support the educational needs of the 4.0 revolution era. This media was developed with the 
iSping application. This product is a learning media that is creative, innovative, and educative so that the evaluation of learning activities is more interactive and fun, which is equipped with evaluation following high order thinking skills indicators of creative thinking. Therefore, this product can improve the creative thinking skills of high school students on Pancasila values persuasively and attractively for use in teaching and learning activities because it uses android technology from smartphones. According to the data obtained, it is known that Srimpi Pandelori dance android based-civic e-learning can have a moderate influence on improving the creative thinking skills of students in first grade at SMA Negeri 1 Ngaglik on Pancasila values.

Indigenous Srimpi Pandelori dance based-android civic e-learning media as a whole has n-gain students' creative thinking skills on Pancasila values of 0.48 in medium category represented in Figure 1.

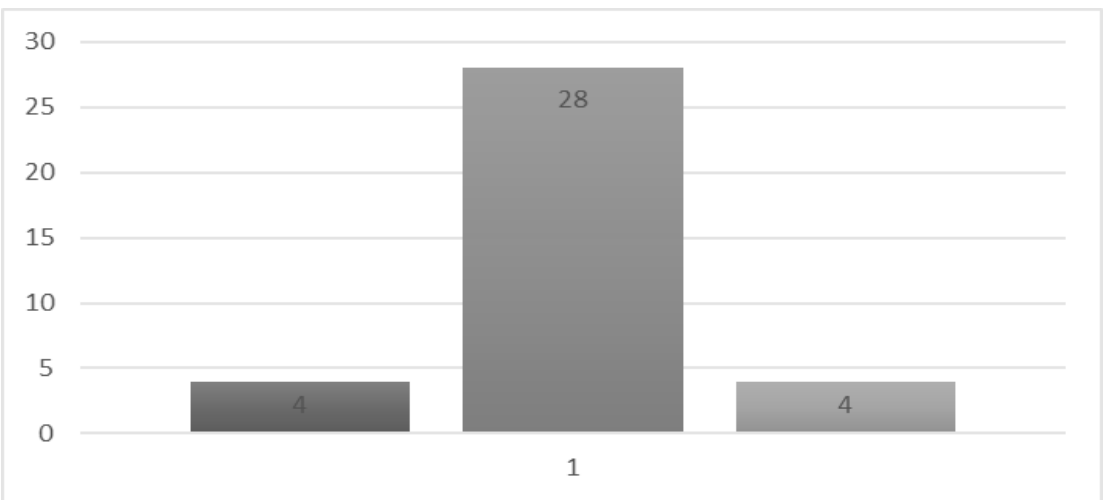

Figure 1. Creative thinking skills n-gain chart

Figure 1 concluded that indigenous Android Srimpi Pandelori dance-based civic e-learning media could improve students' creative thinking skills at SMA Negeri 1 Ngaglik on Pancasila values in the medium category.

Srimpi Pandelori dance is a type of physical culture that contains many educational values and is relevant to life today, especially on Pancasila values. Educational values contained in the Srimpi Pandelori dance, namely: religion, courtesy with others, the responsibility to strengthen national unity and integrity, ethics, and personality. Based on the seven main points thought of Ki Hajar Dewantara, who stated that Srimpi Pandelori dance was not only as a media for sports but also as an educational media. Interpretation of the meaning Srimpi Pandelori's dance movements is one way to understand the value of education contained in character the dance. The intended education value is to help humans to understand, realize, and practice the values and be able to place them integrally the values contained in the Srimpi Pandelori dance movements in daily life following Pancasila values.

Srimpi Pandeloris educational values are relevant to Pancasila values studied as follows: religious values, are a reflection style of motion Sembahan Sila Panggung. It is reflected in the various movements displayed attitude. Sembahan Sila Pnggung is a human weakness picture, as well as proving the existence of God. Sembahan means to worship as spiritual beings appropriate to ask for God's blessing and express gratitude for the blessings that God bestows upon humankind. Manner values are an interpretation style Sembahan Sila Panggung motion. Besides, Sembahan Sila Panggung has the meaning to worship and ask for prayer to God also contains the respect meaning for the king and the guests of the king. Sembahan Sila Panggung is a positive attitude, form as social human beings classified required to respect one another. Responsibility values are an interpretation style of motion Kengser Tasikan. Tasikan means dressing up in Indonesia, but if judging deeper, dressing up is an attempt to oneself take care to respond as God's creatures to care for, maintain, and improve a thanksgiving that has been granted to humans. Every human being is required to have their respective responsibilities in order to create harmony between people. Ethical values are an interpretation style of motion Ecen, Aben Sikut, and Sudukan. The message 
that can be drawn from these three variations will always be a good side and an evil side in humans. The range motion shows a human life choice, with good or bad. A hint of being a person a positive or negative impact on others.

The following personality values are an interpretation style of motion Nglayang. Style Nglayang motion has a meaningful message always to put the heart close to the ground, humble nature must have, calm, and avoid all diseases of the heart, because humility is a patient person and truest reflection. Android indigenous Srimpi Pandelori based-civic elearning is creative, innovative, and educative because of learning activities evaluation is more interactive and fun equipped with evaluation following high order thinking skills indicators of creative thinking. Besides, the application of the PQ4R (Preview, Question, Read, Reflect, Recite, and Review) strategy makes it easy for students to recall learning the topic independently. Therefore, this product can improve the high school students' creative thinking skills on Pancasila values effectively and attractively for teaching and learning activities used because of smartphones android technology. Prior research on innovative learning media has been carried out by several academics on different aspects of research covered. It is mutually reinforced to each other in order to progress the education quality, especially in civic education learning.

Technology utilization in the education world, especially in the learning system, has changed the learning conventional system patterns or traditional patterns into modern patterns utilizing Information and Communication Technology (ICT). Learning Technology utilization allows students to access media and learning activities in an actual way and not limited to time and space. Teachers have to control the learning progress starting from the topic delivery, assignment techniques, learning monitoring progress, and evaluation as a form through quizzes and practice questions assessment. The teacher assesses both the realm of attitudes, knowledge, and skills. It is planned systematically with the innovative support media, especially on learning that is dominant in such material civic education.

Civic education interpreted as preparing the younger generation in shaping learners' skills for citizens' concocting knowledge, skills, and values needed to participate in their communities actively. However, assignments, stimuli, and questions in civic education learning that are designed do not accommodate students to build thinking skills as a whole using interesting and fun learning media so that the learning process will seem monotonous and boring. Therefore, instructional media selection that can train students' thinking skills in civic education subjects is the basis for media development indigenous android Srimpi Pandelori based civic e-learning.

Pancasila values are relevant to Srimpi Pandelori dance's focused on various moves then used as technology-based civic education learning media following the revolution industry 4.0 demands era. Android platform-based technology is the development choice due to widely available media and must be owned by students in Yogyakarta. Indigenous android media based on civic e-learning are applied to civic education learning on Pancasila values to practice creative thinking skills following the demands of the $21^{\text {st }}$ century can be seen in Figure 2.

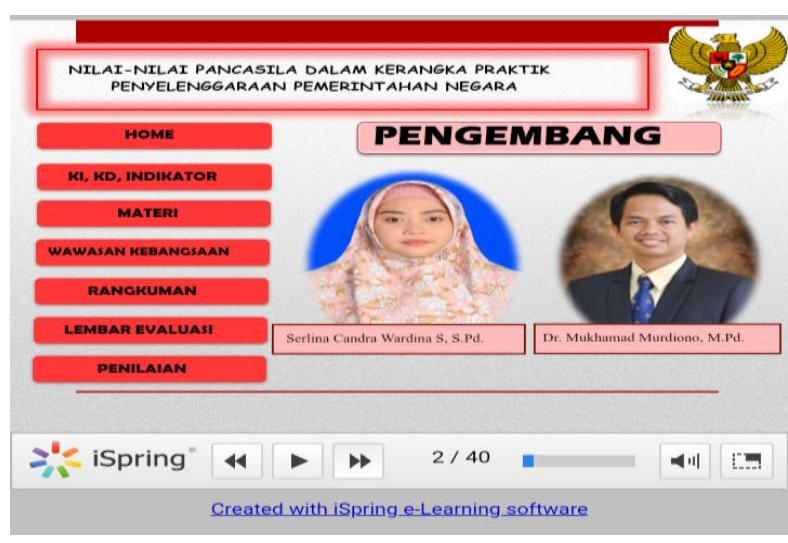

Figure 2. Android civic e-learning 
On the other hand, innovative learning media that trains $21^{\text {st }}$-century skills integrated with 4.0 technology turned out to be significantly able to be a tool in passing the archipelago culture to the younger generation (age 15-16). Future research on media, similar to an indigenous knowledge variety in other areas, can be further research focused on other age ranges. A qualitative study of the effect of using indigenous knowledge on civic education learning will be a research breakthrough that is worth the wait.

\section{Conclusion and Suggestion}

Based on the results of research and discussion, it can be concluded that indigenous Srimpi Pandelori dance based-android civic e-learning media has a significant influence on improving students' creative thinking skills of first grade at SMA Negeri 1 Ngaglik on Pancasila values and indigenous Srimpi Pandelori dance based-android civic e-learning media able to improve students' creative thinking skills in first grade at SMA Negeri 1 Ngaglik on Pancasila values in the medium category.

\section{References}

Ahangari, S. \& Zarrin, S. 2014. The Effect of Cooperative Learning Activities on Skills of Iranian EFL Learners. Journal Linguistics and Literature Studies, 2(4), 121-130. https://doi.org/10.13189/lls.2014.020403.

Bortolini, M., Emilio, F., Mauro, G., Francesco, P., \& Maurizio, F. 2017. Assembly System Design in The Industry 4.0 Era: A General Framework. International Federation of Automatic Control by Elsevier Ltd, 50(1), 5700-5705. https://doi.org/10.1016/j.ifacol.2017.08.1121.

Diani, R., Yuberti, \& M. Ridho, S. 2018. Web-Enhanced Course Based on Problem-Based Learning (PBL): Development of Interactive Learning Media for Basic Physics II. Jurnal Ilmiah Pendidikan Fisika Al-Biruni, 07(01). 105-116. https://doi.org/10.24042/jipfalbiruni.v7i1.2849.

Gitadewi, A., J. 2019. The Effectiveness of Scimago Mobile Learning to Improve Student Motivation and Learning Outcomes. Pendidikan Sains, 7(2), 70-76. https://jurnalmahasiswa.unesa.ac.id/index.php/pensa/article/download/27692/25337.

Gu, X., Ap, D., A., \& Simone, M., R. 2019. Fostering Children's Creative Thinking Skills with the 5-I Training Program. Journal Thinking Skills and Creativity, 32. 92-101. https://doi.org/10.1016/j.tsc.2019.05.002.

Harris, A., \& Leon, R., de Bruin. 2018. Training Teachers for Twenty-First Century Creative and Critical Thinking: Australian Implications from an International Study. Journal Teaching Education, 29(3). 234-250. https://doi.org/10.1080/10476210.2017.1384802.

Hartono. 2016. SPSS 16.0 Analisis Data Statistika dan Penelitian. Yogyakarta: Pustaka Pelajar.

Hendikawati, P., Muhammad, Z. Z., \& Riza, A. 2019. Android-Based Computer Assisted Instruction Development as A Learning Resource for Supporting Self-Regulated Learning. International Journal of Instruction, 12(3), 389-404. https://doi.org/10.29333/iji.2019.12324a.

Ige, O. A. \& Dipane, J. H. 2017. Effects of Computer-Aided and Blended Teaching Strategies on Students' Achievement in Civic Education Concepts in Mountain Learning Ecologies. Journal of Education and Information Technologies, 22(6), 1-17. https://doi.org/10.1007/s10639-017-9598-x.

Im, H., Brad, H., \& Kim, K. P. J. 2015. Teaching Creative Thinking Skills: A Longitudinal Study. Clothing and Textiles Research Journal, 33(2). 129-142. https://doi.org/10.1177/0887302X15569010.

Jacobson, S. K., Jennifer, R. S., \& Robert, C. M. 2016. Integrated Science and Art Education for Creative Climate Change Communication. Journal of Ecology and Society, 21(3), 3037. https://doi.org/10.5751/ES-08626-210330. 
Japar, M., Dini, N. F., Yuyus, K., Yasnita, \& Sarkadi. 2018. Building Democracy of Culture in School Through Jurispudential Inquiry. Jurnal Kependidikan, 2(2), 333-347. https://journal.uny.ac.id/index.php/jk/article/view/18924.

Komara, E. 2017. Curriculum and Civic Education Teaching in Indonesia. International Journal for Educational Studies, 10(1). 23-32. http://journals.mindamas.com/index.php/educare/article/view/929.

Martiniano, C. 2016. The Scientization of Creativity. Journal of the Midwest Modern Language Association, 49(2), 161-190. http://www.jstor.org/stable/44164809.

Meinal, T., \& Rahmawati, R. 2016. The Srimpi Renggowati: A Study of Sustainable Cultural Tourism in the Art of Classical Javanese Dance in Yogyakarta. Asia Tourism Forum 2016 - The 12th Biennial Conference of Hospitality and Tourism Industry in Asia (ATF16), 427-431. https://doi.org/10.2991/atf-16.2016.65.

Prihandoko, Y., St. Y. Slamet, \& Winarno. 2017. Cognitive Moral Approach to Civics Education Material Development in The Elementary School. Jurnal Kependidikan, 1(2), 200-213. https://journal.uny.ac.id/index.php/jk/article/view/15279

Redecker, C. \& Oystein, J. 2013. Changing Assessment-Toward A New Assessment Paradigm Using ICT. European Journal of Education, 48(1), 79-96. https://doi.org/10.1111/ejed.12018.

Ritter, S. M., \& Mostert, N. 2017. Enhancement of Creative Thinking Skills Using A CognitiveBased Creativity Training. Journal of Cognitive Enhancement, 1(3). 243-253. https://doi.org/10.1007/s41465-016-0002-3.

Safara, A., M. Zaim, \& Refnaldi. 2019. Mobile-Based Learning in Digital Era: Android Application as A Media to Teach Grammar. 1st International Conference on Education, Social Sciences and Humanities (ICESSHum 2019), 335, 1019-1025. https://doi.org/https://doi.org/10.2991/icesshum-19.2019.157.

Safitri, M., Sunu, K., \& Endang, S. 2018. Metacognitive Strategies to Train Creative Thinking Skills in Creating Media for Learning. Mathematics, Informatics, Science, and Education International Conference (MISEIC 2018) Advanced in Intelligent Systems Research (AISR), 157, 231-233. https://doi.org/10.2991/miseic-18.2018.56.

Sitorus, J. H. E. 2016. Pancasila-Based Social Responsibility Accounting. Procedia-Social and Behavioral Sciences 3rd Global Conference on Business and Social Science, 2019, 700-709. https://doi.org/10.1016/j.sbspro.2016.05.054.

Stoddard, J., Angela, M. B., Christine, N., \& Elizabeth, W. 2016. The Challenges of Gaming for Democratic Education: The Case of iCivics. Journal of Democracy \& Education, 23(2), 1-12. https://democracyeducationjournal.org/home/vol24/iss2/2/.

Sukoyo, J. 2017. The Effectiveness of Javanese Songs in Cultivating Students' Characters. Jurnal Kependidikan, 1(2), 163-173. https://journal.uny.ac.id/index.php/jk/article/view/10753.

Suratno, Nurul, K., Yushardi, Daflik, \& Iwan, W. 2019. The Effect of Using Synectics Model on Creative Thinking and Metacognition Skills of Junior High School Students. International Journal of Instruction, 12(3). 133-150. https://doi.org/10.29333/iji.2019.1239a.

Taib, M. F., Gabriel, L. L. S., Soedarsono, R. M., \& A.M. Hermien, K. 2014. Non-Formal Education as Culture Transformation Agent Toward the Development of Clasical Court Dance in Yogyakarta, Indonesia. International Journal of Education and Research, 2(5). 43-52. https://www.ijern.com/journal/May-2014/04.pdf.

Triyono, Senam, Jumadi, \& Insih, W. 2017. The Effects of Creative Problem Solving-Based Learning Towards Students' Creativities. Jurnal Kependidikan, 1(2), 214-226. https://journal.uny.ac.id/index.php/jk/article/view/9429.

Tur, G. \& Victoria, I. M. 2015. Enchancing Learning with the Social Media: Student Teachers' Perceptions on Twitter in A Debate Activity. New Approaches in Educational Research, 4(1), 46-53. https://doi.org/10.7821/naer.2015.1.102.

Tyas, G. P. 2018. Nilai Pendidikan Karakter dalam Ragam Gerak Tari Srimpi Pandelori. Mudra Jurnal Seni Budaya, 33(2), 182-189. https://doi.org/10.31091/mudra.v33i2.329. 
Widiana, I. W., I Made, S., \& Ni Putu, I. C. D. 2019. Optimizing Project-Based Try Activity to Improve the Dimension of Students' Cognitive Process. Jurnal Kependidikan, 3(1), 1527. https://journal.uny.ac.id/index.php/jk/article/view/14422.

Widiansyah, A. T., Indriwati, S. E., Munzil, M., \& Fauzi, A. (2018). I-Invertebrata as An AndroidBased Learning Media for Molluscs, Arthropods, and Echinoderms Identification, and Its Influence on Students' Motivation. Jurnal Pendidikan Biologi Indonesia, 4(1). 43-51. https://doi.org/10.22219/jpbi.v4i1.5476. 